\title{
Design of Risk Management Based on Iso 31000 in PDAM Tirta Meulaboh
}

\author{
Zainal Putra ${ }^{*}$, Syafruddin Chan ${ }^{2}$, and Moenawar IHA ${ }^{3}$ \\ ${ }^{1,3}$ Teuku Umar University, Meulaboh, Indonesia \\ ${ }^{2}$ Syiah Kuala University, Banda Aceh, Indonesia
}

\begin{abstract}
Regional Water Company (PDAM) Tirta Meulaboh is the only state- ownedof West Aceh district that provides clean water for the residents of West Aceh, especially the residents of the city of Meulaboh and its surroundings. But in its operation the company has not yet to have a risk management system, so it has the impact on the company's survival and not optimal service to its customers. The study aims to identify risk, risk analysis and risk evaluation, in order to do prevention and mitigation of the impact of risk on each section in PDAM Tirta Meulaboh using risk management system standard ISO 31000. The process steps of risk management based on ISO 31000, starting from risk identification to methods Risk Breakdown Structure (RBS), risk analysis using matrix risk quantification and Risk Priority Number (RPN), and the evaluation of risks by using risk map. The results showed that in PDAM Tirta Meulaboh there were 43 risk events that have the potential business problems, which if they were not solved immediately it could affect the performance of the company, even the survival of the company. Of the 43 potential risks that were logged to the red zone, there were 5 potential risks which occupies the first rank is on productions departement: the defective of production water meter, the defective of distribution water meter and retrieval water by tank car without through the water meter. Branch Kaway XVI: customers are reluctant to pay the water bill and in IKK Rantau Panjang: water meter of raw water was damaged. The Efforts to mitigate against the risk of those 43 events which were logged in the red zone has not been planned and done yet by the management of PDAM Tirta Meulaboh.
\end{abstract}

Keywords: ISO 31000, PDAM Tirta Meulaboh, Risk Management

\section{INTRODUCTION}

Risk is everywhere, can come at any time and are difficult to avoid. If such risks overwrite the organization, then the organization could experience significant losses. In some situations, the risk could lead to the destruction of the organization. So it is important risk to manage the risk. Risk management organization aims to create a system or mechanism within the organization so that the risks that could harm the organization can be anticipated and managed for the purpose of increasing the company's value (Hanafi, 2014: 8).

\footnotetext{
* Corresponding author. Email address: zainalputra@utu.ac.id
} 
Risk management in an enterprise will be very helpful in several ways, namely: (a). Foreseeing the base, the magnitude and frequency of potential losses suffered when an event occurred that could not previously suspected, (b). Creating a basis for reducing or limiting the emergence of a risk, (c). Provide a basis for a decision to estimate the risks that may arise. So risk management is an executive decision which aims at managing the risks that would be faced by the company, which can result in losses for the company (Harimurti in Abisay and Nurhadi, 2013).

Companies will always face an uncertain work environment, so that every company faces risks. PDAM Tirta Meulaboh is the only state- owned West Aceh district that provides clean water for the residents of West Aceh, especially the residents of the city of Meulaboh and its surroundings.

In this case, PDAM Tirta Meulaboh have not been able to provide optimum service to the community. This is evidenced by the frequent customer complaints were reported in the local media about murky water, salty water, muddy water, and the water was not drain.

From the author's observation, it was also known that the company does not yet have adequate risk management systems. This was reflected due to the time of the study, PDAM Tirta Meulaboh has not yet to have a risk management document.

Supposedly every company must establish adequate risk management systems in order to ensure the survival of the company and can provide optimal service to the customers.

Therefore, it is necessary to study to design a risk management system in PDAM Tirta Meulaboh with reference to international standards.

The study aims to identify risk, risk analysis, risk evaluation to be carried out as prevention and mitigation of the impact of risk on each section in PDAM Tirta Meulaboh by using the risk management system of international standard.

With this research, the benefits of a good understanding of risk management based on ISO 31000 standards and able to develop the design of prevention and risk control system.

Previous research related to this topic has been done by Febriyanti and Hidayanto (2012), with the title of the study of risk management for data management in the data processing section of PT Petro Kimia Gresik. Dewi (2012), examines the implementation of a risk management system for the national industry as input for nuclear power programs.

Abisay and Nurhadi (2013), examines the risk management at Soekarno Hatta Airport based on ISO 31000. Nurochman (2014), examines the risk management library information system (a case study in the library of University of Gajah Mada). Li Guo (2015), examines the implementation of a risk management plan in operating room of Peking University Third Hospital.

We can claim that is this study differs from previous studies, due to the characteristics of different companies, so that the results of research and discussion differ from the previous research. 


\section{LITERATURE STUDY}

\section{Understanding Risks and Risk Management}

Tugiman (2009), defines risk as an adverse event or not achieving the expected goals. Risks associated with uncertainty. This uncertainty happens due to the lack or unavailability of information about what is going to happen. For organizations, especially companies unpredictability can be detrimental or beneficial impact. If uncertainty profitable then it is called opportunity. While uncertainty is detrimental then known as risk.

CPPR MEP UGM (2012: 2) define risk as an opportunity or possibility of danger, loss, injury, or other unintended consequences. According to Dewi (2012), the risk is the possibility of adverse events. The same thing was said by Hanafi (2014: 1), which defines risk as an adverse event. Another defined that is often used for investment analysis, is the possibility of the results obtained deviates from the expected. Risk is the uncertainty that may be a positive or negative expectation

Meanwhile, the organization's risk management according to Mamduh in Tugiman (2009), is an organization's risk control system faced by organizations in a comprehensive manner for the purpose of increasing the company's value. Also SBC Warburg in Tugiman (2009) said that risk management is a set of policies, procedures complete, that belong to organizations to manage, monitor and control the organization's exposure to risk. Gibson in Nurochman (2014), defines risk management as a practical activity on the identification, assessment, control and mitigation of risk. Likewise Hanafi (2014: 9), said risk management is how an organization can manage the risks it faces. Basically, risk management is done through a process of risk identification, evaluation, risk measurement and risk management.

Each organization must be able to manage the risks. If organizations fail to manage risk, the consequences could be serious enough and certainly detrimental to the company. According to Hanafi (2014: 11), there were six ways to manage organizational risk, namely avoidance, detained, diversification, risk transfer, risk control and risk financing.

\section{ISO 31000 and Risk Management Process}

With the various risk management standards and global consensus in risk management, the International Standards Organization (ISO), started to draw up a risk management standards. After going through the voting process and the revision of all the members of ISO, the standard was launched as an international standard (Susilo and Kaho, 2010: 6). By stating that ISO 31000 is a generic risk management standard, this standard does not negate the risk management standards created for specific. Both can co-exist and complement each other. One thing that distinguishes the ISO 31000 with other risk management standard that ISO 31000 is broader and more conceptual than others.

The risk management process includes five activities, namely communication and consultation, determine the context, risk assessment, risk treatment and monitoring as well as the Review. For the risk assessment it self includes three parts in it: risk identification, risk analysis and risk evaluation. 


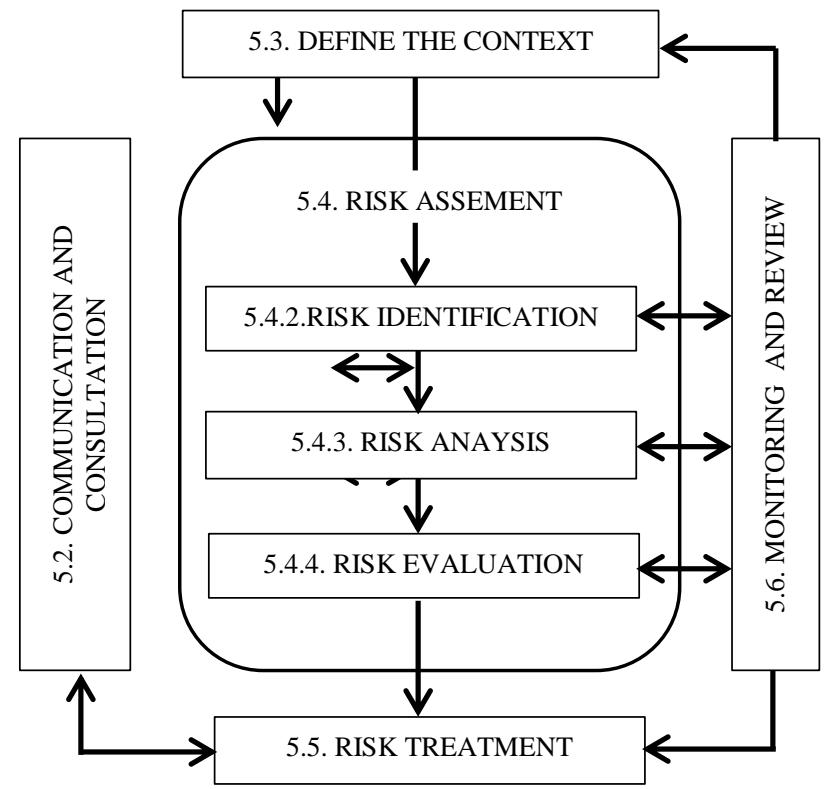

Figure 1 Process Risk Management According to ISO 31000 Source: Susilo, L.J. and Kaho, V.R. (2010: 78).

Meanwhile, according to Peltier (2004), there are six stages in the process of risk analysis, namely the definition of an asset, threat identification, determine the probability of occurrence, determine the impact of threats, recommendations and documentation control.

Risk mitigation is a systematic methodology that is used by senior management to reduce the risk of the organization. There are five methods in mitigating risk, the acceptance of risk (risk assumption), the reduction of risk (risk Alleviation), risk aversion (risk avoidance), the limitation of risk (risk limitation) and planning risk (risk planning) (Peltier, 2004).

\section{RESEARCH METHODOLOGY}

The research method of risk management was done based on ISO 31000. The phases starting from risk identification, risk analysis and risk evaluation.

Risk identification aims to identify risks that must be managed by the organization through a systematic and structured process. This process is very important because the risks are not identified in this process will not be dealt with in the production process. Risk identification target is to develop a list of sources of risk and a comprehensive events as well as having an impact on the achievement of the goals and targets identified from the context. The main document that is generated in this process is a list of risk

Risk identification was done by the method of Risk Breakdown Structure (RBS), followed by brainstorming with the employee responsible for each section, including the top leaders.

Risk analysis is an attempt to more deeply understand the risks, including ways and strategies in treating those risks. The purpose of risk analysis is to analyze 
the impact and possibilities of all the risks that may impede the achievement of the organization's objectives. Event risk is analyzed using matrix quantification of risk, then the risk is classified in the red, yellow or green, according to its level. Risk quantification matrix can be seen in Table 1 .

The purpose of risk assessment is to help the decision-making process based on the results of risk analysis. Risk evaluation process will determine which risks need treatment and how to treat priority over those risks.

Treatment risks include efforts to select the options that can reduce or negate the impact and likelihood of risk occurrence, then apply the selection.

Tabel 1 - Risk Quantification Matrix

\begin{tabular}{lcccccc}
\hline \multirow{2}{*}{ Likelihood } & \multicolumn{6}{c}{ Consequence } \\
\cline { 2 - 7 } & \cline { 2 - 7 } & Insignificant & Minor & Moderate & Major & Extreme \\
\cline { 2 - 7 } & $\mathbf{1}$ & $\mathbf{2}$ & $\mathbf{3}$ & $\mathbf{4}$ & $\mathbf{5}$ \\
\hline Almost Certain & 5 & 5 & 10 & 15 & 20 & 25 \\
\hline Likely & 4 & 4 & 8 & 12 & 16 & 20 \\
\hline Possible & 3 & 3 & 6 & 9 & 12 & 15 \\
\hline Unlikely & 2 & 2 & 4 & 6 & 8 & 10 \\
\hline Remote & 1 & 1 & 2 & 3 & 4 & 5 \\
\hline
\end{tabular}

Source: Li Guo (2015)

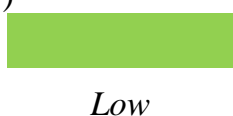

Low
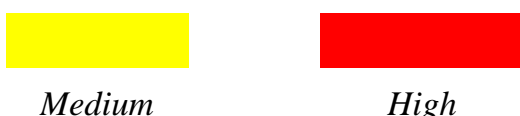

High

\section{RESULTS AND DISCUSSION Organization Overview}

PDAM Tirta Meulaboh is a business entity owned by the Government of West Aceh which was founded in 1983 under the name Water Management Agency (BPAM). The Company began operations in 1984. Based on Regional Regulation No. 11 of 1993, it renamed to became PDAM Tirta Meulaboh. The company has the mission of "Excellent Service, Healthy and Independent".

Based on data as of February 2016, the service of the company covered three districts:

a. Johan Pahlawan sub-district: the number of customers 4,668 house connections (SR).

b. Kawai XVI Subdistrict: the number of customers 1,546 house connections (SR).

c. Meureubo Subdistrict: customer number 246 house connections (SR).

PDAM Tirta Meulaboh has three water treatment facilities (Water Treatment Plant / WTP), located in the lapang village, Johan Pahlawan subdistrict, in IKK Rantau Panjang, Meureubo subdistrict and in Beureugang village, Kaway XVI subdistrict.

The company located at Jalan Purnama Meulaboh No. 01, has an installed production capacity of 6.14952 million $\mathrm{m} 3$, with the volume of water produced 
reaches 2.1024 million $\mathrm{m} 3$. The company has 51 permanent employees and assisted by 19 contract employees.

\section{Risk Identification}

Risk identification in this study is done by testing the document by using Risk Breakdown Structure (RBS) method, conducting interviews and brainstorming with the stakeholders related. From the document test results, obtained the information that there were as many as 9 units under PDAM Tirta Meulaboh have potential risk, namely the financial, administrative and general, IKK Rantau Panjang, Branch of Kaway XVI, part of customer relations and account, planning section and supervision, production and transmission and distribution units. The risk is described in figure 1. Based on interviews and brainstorming with related stakeholders, can be identified as many as 54 risks.

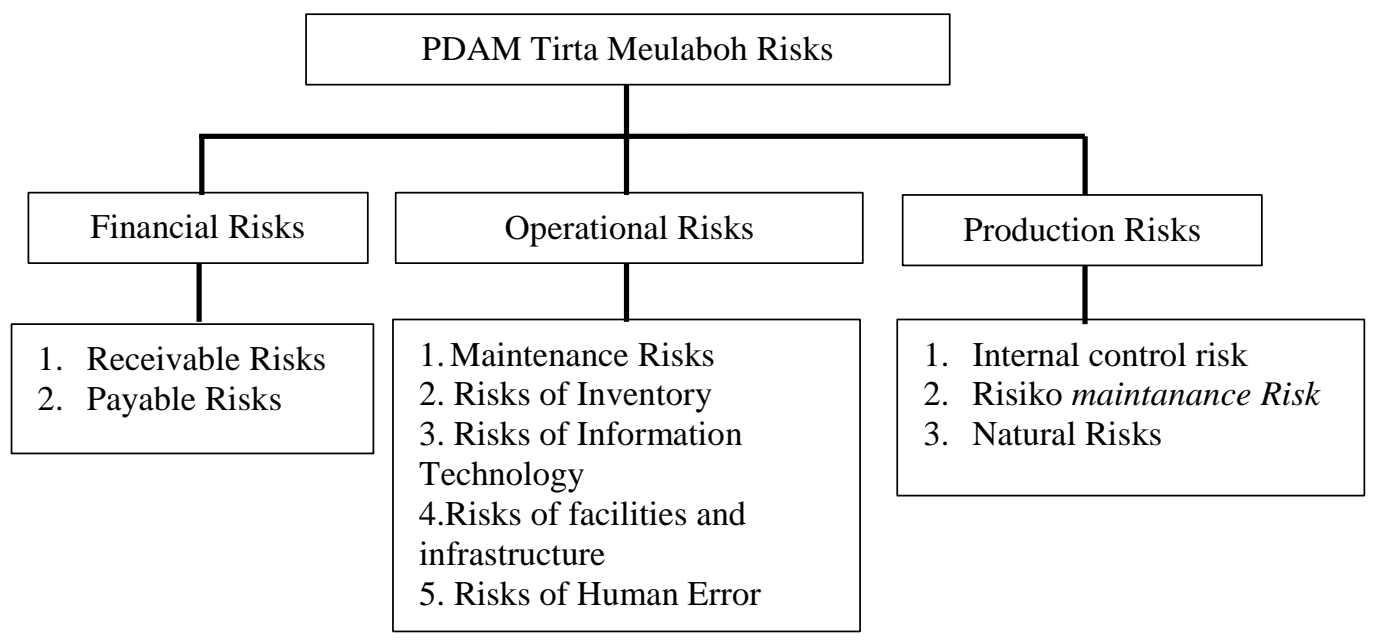

Figure 1 RBS PDAM Tirta Meulaboh

\section{Risk Analysis}

In this study, the risk analysis process was done using quantitative methods with qualitative parameters. Assessment was done by distributing questionnaires to get answers from the respondents. The respondents were 12 people whowere related risk stakeholders of PDAM Tirta Meulaboh. The questionnaire was divided into two parts, the possible risks and impacts.

The questionnaire has been tested by using normality test, validity and reliability test of SPSS software. Normality test was done by using KolmogorovSmirnov methods. The resalt indikacted that the data were normally distributed, both variable and variable risk of impact, as shown in figure 2 and figure 3 .

Tests of Normality

\begin{tabular}{ccccccc}
\hline & \multicolumn{3}{c}{ Kolmogorov-Smirnov $^{\mathrm{a}}$} & \multicolumn{3}{c}{ Shapiro-Wilk } \\
\cline { 2 - 7 } Risk & Statistic & df & Sig. & Statistic & df & Sig. \\
\cline { 2 - 7 } & 0,138 & 12 & $0,200^{*}$ & 0,962 & 12 & 0,815 \\
\hline
\end{tabular}

Figure 2 Result of Nornality Test for The Risk Variable 
Tests of Normality

\begin{tabular}{ccccccc}
\hline & \multicolumn{3}{c}{ Kolmogorov-Smirnov $^{\mathrm{a}}$} & \multicolumn{3}{c}{ Shapiro-Wilk } \\
\cline { 2 - 7 } & Statistic & df & Sig. & Statistic & df & Sig. \\
\hline Impact & 0,169 & 12 & $0,200^{*}$ & 0,961 & 12 & 0,791 \\
\hline
\end{tabular}

Figure 3 Results Of Normality Test For The Impact Variable

From Figure 2 and Figure 3 above, indicated that each number KolmogorovSmirnov test of significance Sig. $=0.200>\alpha=0.05$, which means that the data distributed normally. Validity test results show that all the items in the questionnaire were valid question. Furthermore, the reliability test gave risk variables Cronbach's Alpha value of 0.917. While the impact of variable reliability test gives Cronbach's Alpha value of 0.897. Each value of Cronbach's Alpha, both impact variable and risk variable were more than 0.60 , which means that the questionnaire of risk variables and impact variables were reliable.

Event risk that had been analyzed, then be put on the red, yellow or green zone. All the risks in the red zone became priority to receive special treatment in the form of further treatment, so-called Risk Priority Numbers (RPN), as presented in Table 2.

Table 2 Risk RPN for events in the Red Zone

\begin{tabular}{|c|c|c|c|c|c|c|}
\hline $\begin{array}{l}\text { Kode } \\
\text { R/D* }\end{array}$ & Unit & Risks & $\mathbf{K K}^{*}$ & $\mathbf{D}^{*}$ & RPN* & Rangking \\
\hline 1 & $\begin{array}{l}\text { Financial } \\
\text { department }\end{array}$ & $\begin{array}{l}\text { Arrears of customer accounts } \\
\text { (accounts receivable). }\end{array}$ & 4 & 5 & 20 & 2 \\
\hline 3 & $\begin{array}{l}\text { Financial } \\
\text { department }\end{array}$ & $\begin{array}{l}\text { Water from reservoir be put in the } \\
\text { water tank car, so it was not recorded } \\
\text { in a water meter. }\end{array}$ & 4 & 5 & 20 & 2 \\
\hline 4 & $\begin{array}{l}\text { Financial } \\
\text { department }\end{array}$ & $\begin{array}{l}\text { The company's long-term debt from } \\
\text { the Ministry of Finance since 1996- } \\
2015 \text {. }\end{array}$ & 4 & 4 & 16 & 3 \\
\hline 5 & $\begin{array}{l}\text { Financial } \\
\text { department }\end{array}$ & $\begin{array}{l}\text { Debt of chemicals alum from } \\
\text { supplier. }\end{array}$ & 4 & 4 & 16 & 3 \\
\hline 6 & $\begin{array}{l}\text { Financial } \\
\text { department }\end{array}$ & $\begin{array}{l}\text { Debt of employee's pension fund at } \\
\text { Dapenmapamsi. }\end{array}$ & 4 & 5 & 20 & 2 \\
\hline 7 & $\begin{array}{l}\text { Financial } \\
\text { department }\end{array}$ & Debt of electricity from PLN & 4 & 5 & 20 & 2 \\
\hline 8 & $\begin{array}{l}\text { Financial } \\
\text { department }\end{array}$ & $\begin{array}{l}\text { Company debt of the social security } \\
\text { contribution on BPJS. }\end{array}$ & 4 & 5 & 20 & 2 \\
\hline 9 & $\begin{array}{l}\text { Financial } \\
\text { department }\end{array}$ & Debt of salary of supervisory board. & 4 & 4 & 16 & 3 \\
\hline 10 & $\begin{array}{l}\text { Financial } \\
\text { department }\end{array}$ & Debt of employee meal & 4 & 5 & 20 & 2 \\
\hline 11 & $\begin{array}{l}\text { Adm Section } \\
\text { and General }\end{array}$ & Late order of alum. & 4 & 5 & 20 & 2 \\
\hline
\end{tabular}




\begin{tabular}{|c|c|c|c|c|c|c|}
\hline $\begin{array}{l}\text { Kode } \\
\text { R/D* }\end{array}$ & Unit & Risks & $\mathbf{K K}^{*}$ & $D^{*}$ & RPN* & Rangking \\
\hline 15 & $\begin{array}{l}\text { IKK Rantau } \\
\text { Panjang }\end{array}$ & $\begin{array}{l}\text { Less stable of electric current from } \\
\text { PLN }\end{array}$ & 4 & 5 & 20 & 2 \\
\hline 17 & $\begin{array}{l}\text { IKK Rantau } \\
\text { Panjang }\end{array}$ & Leaks in distribution pipes. & 4 & 4 & 16 & 3 \\
\hline 18 & $\begin{array}{l}\text { IKK Rantau } \\
\text { Panjang }\end{array}$ & Turbid water. & 4 & 4 & 16 & 3 \\
\hline 19 & $\begin{array}{l}\text { IKK Rantau } \\
\text { Panjang }\end{array}$ & Delays of alum delivery & 4 & 5 & 20 & 2 \\
\hline 20 & $\begin{array}{l}\text { IKK Rantau } \\
\text { Panjang }\end{array}$ & Shortage of maintenance funds. & 4 & 4 & 16 & 3 \\
\hline 21 & $\begin{array}{l}\text { IKK Rantau } \\
\text { Panjang }\end{array}$ & $\begin{array}{l}\text { Distribution pumps only } 1 \text { unit being } \\
\text { used of } 3 \text { units available. }\end{array}$ & 4 & 4 & 16 & 3 \\
\hline 22 & $\begin{array}{l}\text { IKK Rantau } \\
\text { Panjang }\end{array}$ & $\begin{array}{l}4 \text { units of alum mixer machines and } 3 \\
\text { units of alum dozing machines that } \\
\text { have been installed by a partner since } \\
2015 \text { were not working. }\end{array}$ & 4 & 4 & 16 & 3 \\
\hline 23 & $\begin{array}{l}\text { IKK Rantau } \\
\text { Panjang }\end{array}$ & Water meters was damaged. & 5 & 5 & 25 & 1 \\
\hline 24 & $\begin{array}{l}\text { IKK Rantau } \\
\text { Panjang }\end{array}$ & office furniture were unusable. & 4 & 4 & 16 & 3 \\
\hline 26 & $\begin{array}{l}\text { Branch of } \\
\text { Kaway XVI }\end{array}$ & Turbid water. & 4 & 4 & 16 & 3 \\
\hline 27 & $\begin{array}{l}\text { Branch of } \\
\text { Kaway XVI }\end{array}$ & unstable electric current (often fails). & 4 & 4 & 16 & 3 \\
\hline 28 & $\begin{array}{l}\text { Branch of } \\
\text { Kaway XVI }\end{array}$ & $\begin{array}{l}\text { Most customers in Blang Beurandang } \\
\text { were no not get water supply. }\end{array}$ & 4 & 5 & 20 & 2 \\
\hline 29 & $\begin{array}{l}\text { Branch of } \\
\text { Kaway XVI }\end{array}$ & $\begin{array}{l}\text { Distribution pumps could not be used } \\
\text { continuously. }\end{array}$ & 4 & 5 & 20 & 2 \\
\hline 30 & $\begin{array}{l}\text { Branch of } \\
\text { Kaway XVI }\end{array}$ & $\begin{array}{l}\text { Customers reluctant to pay their } \\
\text { water bill. }\end{array}$ & 5 & 5 & 25 & 1 \\
\hline 31 & $\begin{array}{l}\text { Branch of } \\
\text { Kaway XVI }\end{array}$ & $\begin{array}{l}\text { Complaints from customers presented } \\
\text { directly to the head of the branch. }\end{array}$ & 4 & 5 & 20 & 2 \\
\hline 32 & $\begin{array}{l}\text { Part of } \\
\text { Customer } \\
\text { Relationship } \\
\text { and Account }\end{array}$ & $\begin{array}{l}\text { Error record water meter at the } \\
\text { customer's home. }\end{array}$ & 4 & 4 & 16 & 3 \\
\hline 33 & $\begin{array}{l}\text { Part of } \\
\text { Customer } \\
\text { Relationship } \\
\text { and Account }\end{array}$ & Water meter was lost. & 4 & 4 & 16 & 3 \\
\hline 34 & $\begin{array}{l}\text { Part of } \\
\text { Customer } \\
\text { Relationship } \\
\text { and Account }\end{array}$ & Complained by customers & 4 & 5 & 20 & 2 \\
\hline 35 & $\begin{array}{l}\text { Part of } \\
\text { Customer } \\
\text { Relationship } \\
\text { and Account }\end{array}$ & $\begin{array}{l}\text { Customer's home were not be able to } \\
\text { be identified }\end{array}$ & 4 & 5 & 20 & 2 \\
\hline 36 & $\begin{array}{l}\text { The Planning } \\
\text { and Control }\end{array}$ & $\begin{array}{l}\text { Data base of transmission and } \\
\text { distribution pipelines inaccurate. }\end{array}$ & 4 & 5 & 20 & 2 \\
\hline
\end{tabular}




\begin{tabular}{|c|c|c|c|c|c|c|}
\hline $\begin{array}{l}\text { Kode } \\
\text { R/D* }\end{array}$ & Unit & Risks & $\mathbf{K K}^{*}$ & $\mathbf{D}^{*}$ & RPN* & Rangking \\
\hline 37 & $\begin{array}{l}\text { The Planning } \\
\text { and Control }\end{array}$ & $\begin{array}{l}\text { Installation of transmission and } \\
\text { distribution pipelines by the } \\
\text { contractor did not comply with the } \\
\text { specification. }\end{array}$ & 4 & 5 & 20 & 2 \\
\hline 38 & $\begin{array}{l}\text { The Planning } \\
\text { and Control }\end{array}$ & $\begin{array}{l}\text { Monitoring software for water } \\
\text { pressure was not yet available }\end{array}$ & 4 & 5 & 20 & 2 \\
\hline 41 & $\begin{array}{l}\text { Warehousing } \\
\text { Dept. }\end{array}$ & Flood & 4 & 4 & 16 & \\
\hline 42 & $\begin{array}{l}\text { Production } \\
\text { Dept. }\end{array}$ & Turbid water. & 4 & 5 & 20 & 2 \\
\hline 43 & $\begin{array}{l}\text { Production } \\
\text { Dept. }\end{array}$ & Burning of the intake pump & 4 & 5 & 20 & 2 \\
\hline 46 & $\begin{array}{l}\text { Production } \\
\text { Dept. }\end{array}$ & Red colored water. & 4 & 4 & 16 & 3 \\
\hline 48 & $\begin{array}{l}\text { Production } \\
\text { Dept. }\end{array}$ & $\begin{array}{l}\text { Laboratory equipment incomplete } \\
\text { and laboratory reagents have been } \\
\text { expired. }\end{array}$ & 4 & 4 & 16 & 3 \\
\hline 49 & $\begin{array}{l}\text { Production } \\
\text { Dept. }\end{array}$ & Water meter production was damaged & 5 & 5 & 25 & 1 \\
\hline 50 & $\begin{array}{l}\text { Production } \\
\text { Dept. }\end{array}$ & $\begin{array}{l}\text { Water meter distribution was } \\
\text { damaged. }\end{array}$ & 5 & 5 & 25 & 1 \\
\hline 51 & $\begin{array}{l}\text { Production } \\
\text { Dept. }\end{array}$ & $\begin{array}{l}\text { There is no water meter for water } \\
\text { tank car. }\end{array}$ & 5 & 5 & 25 & 1 \\
\hline 52 & $\begin{array}{l}\text { Transmission } \\
\text { and } \\
\text { Distribution } \\
\text { Section }\end{array}$ & $\begin{array}{l}\text { Leaks in the } p \text { transmission and } \\
\text { distribution pipelines. }\end{array}$ & 4 & 4 & 16 & 3 \\
\hline 53 & $\begin{array}{l}\text { Transmission } \\
\text { and } \\
\text { Distribution } \\
\text { Section }\end{array}$ & The occurrence of illegal connections & 4 & 5 & 20 & 2 \\
\hline 54 & $\begin{array}{l}\text { Transmission } \\
\text { and } \\
\text { Distribution } \\
\text { Section }\end{array}$ & $\begin{array}{l}\text { The water supply to the customer was } \\
\text { stop }\end{array}$ & 4 & 5 & 20 & 2 \\
\hline
\end{tabular}

Note: $* \mathrm{KK}=$ Kemungkinan Kejadian, $* \mathrm{D}=$ Dampak, $* \mathrm{R} / \mathrm{D}=$ Risiko/Dampak

\section{Risk Evaluation}

The purpose of the risk evaluation process is to determine the priority of risk management in order to know any risks that require attention and further treatment. This phase was conducted to determine how much risk was extreme, major, moderate, minor or insignificant. The risk classification can be seen on a map of risk presented in Table 3.

From a total of 55 potential risks identified, 43 potential risks $(78.18 \%)$ were included in the red zone, consist of 9 potential risk from finance department, one from administration and the public department, , 9 potential risks from IKK Rantau Panjang, 6 from Kaway XVI Branch, 4 from customer relations and account 
department, 3 from planning and supervision, 1 from warehousing, 7 from production department and 3 potential risk from transmission and distribution.

Furthermore, the potential risks that fall into the red zone were ranked in accordance with the value of the RPN. The objective was to facilitate in determining the priority of risk mitigation. From table 1 above, there are 5 potential risks which occupies the first rank, in the second rank there were 21 potential risks and the remaining 17 potential risks logged in third rank. Potential risks were included in the red zone should receive serious attention from the management to be handled immediately.

Table 3 Risk Map of PDAM Tirta Meulaboh

\begin{tabular}{|c|c|c|c|c|c|c|}
\hline \multirow{3}{*}{ Likelihood } & & \multicolumn{5}{|c|}{ Consequence } \\
\hline & & Insignificant & Minor & Moderate & Major & Extreme \\
\hline & & 1 & 2 & 3 & 4 & 5 \\
\hline Almost Certain & 5 & & & & & $\begin{array}{l}\text { R23, R30, R49, } \\
\text { R50, R51 }\end{array}$ \\
\hline Likely & 4 & & & & $\begin{array}{l}\text { R4, R5, R9, } \\
\text { R17, R18, } \\
\text { R20, R21, } \\
\text { R22, R24, } \\
\text { R26, R27, } \\
\text { R32, R33, } \\
\text { R41, R46, } \\
\text { R48, R52 }\end{array}$ & $\begin{array}{l}\text { R1, R3, R6, } \\
\text { R7, R8, R10, } \\
\text { R11, R15, R19, } \\
\text { R28, R29, R31, } \\
\text { R34, R35, R36, } \\
\text { R37, R38, R42, } \\
\text { R43, R53, R54 }\end{array}$ \\
\hline Possible & 3 & & & & $\begin{array}{c}\mathrm{R} 2, \mathrm{R} 13, \\
\mathrm{R} 16, \mathrm{R} 25, \\
\mathrm{R} 45, \mathrm{R} 47\end{array}$ & $\begin{array}{l}\text { R14, R39, R44, } \\
\text { R55 }\end{array}$ \\
\hline Unlikely & 2 & & & $\mathrm{R} 12$ & R40 & \\
\hline Remote & 1 & & & & & \\
\hline
\end{tabular}

\section{Treatment Risks}

Risk treatment system was designed to assist managers in making decisions. Because in general the potential risks were identified based on events that happened before, then the election strategy of risk treatment performed in this study was to mitigate risk, as presented in Table 4. 
Table 4 Risk Mitigation Strategy Loggof ed in Red Zone

\begin{tabular}{|c|c|c|c|c|c|}
\hline $\begin{array}{l}\text { Code } \\
\mathbf{R} / \mathbf{D}^{*}\end{array}$ & Unit & Risks & Causes & Impact & $\begin{array}{c}\text { Mitigation } \\
\text { Strategy }\end{array}$ \\
\hline 1 & $\begin{array}{l}\text { Financial } \\
\text { department }\end{array}$ & $\begin{array}{l}\text { Arrears of customer } \\
\text { accounts (accounts } \\
\text { receivable). }\end{array}$ & $\begin{array}{l}\text { (A). Customers are } \\
\text { reluctant to pay the } \\
\text { bills, and (b) } \\
\text { Customer less } \\
\text { satisfied with the } \\
\text { services }\end{array}$ & $\begin{array}{l}\text { Constrained in the } \\
\text { implementation } \\
\text { of the company's } \\
\text { operations }\end{array}$ & $\begin{array}{l}\text { (A) To form billing } \\
\text { team and (b) To stop } \\
\text { water connections. }\end{array}$ \\
\hline 3 & $\begin{array}{l}\text { Financial } \\
\text { department }\end{array}$ & $\begin{array}{l}\text { Water from } \\
\text { reservoir be put in } \\
\text { the water tank car, } \\
\text { so it was not } \\
\text { recorded in a water } \\
\text { meter. }\end{array}$ & $\begin{array}{l}\text { Mains water meter } \\
\text { was damaged }\end{array}$ & $\begin{array}{l}\text { The potential } \\
\text { occurrence of } \\
\text { fraud that may } \\
\text { harm the } \\
\text { company's } \\
\text { finances. }\end{array}$ & $\begin{array}{l}\text { Supply and } \\
\text { installation of water } \\
\text { meters for water } \\
\text { collection by water } \\
\text { tank car }\end{array}$ \\
\hline 4 & $\begin{array}{l}\text { Financial } \\
\text { department }\end{array}$ & $\begin{array}{l}\text { The company's } \\
\text { long-term debt from } \\
\text { the Ministry of } \\
\text { Finance since 1996- } \\
2015 \text {. }\end{array}$ & $\begin{array}{l}\text { Installment } \\
\text { repayment had } \\
\text { never been done }\end{array}$ & $\begin{array}{l}\text { Financial burden } \\
\text { on the company. }\end{array}$ & $\begin{array}{l}\text { Grant from central } \\
\text { government to local } \\
\text { government } \\
\text { through APBK } 2017\end{array}$ \\
\hline 5 & $\begin{array}{l}\text { Financial } \\
\text { department }\end{array}$ & $\begin{array}{l}\text { Debt of chemicals } \\
\text { alum from supplier. }\end{array}$ & $\begin{array}{l}\text { The lack of } \\
\text { payment of water } \\
\text { bills by customers, } \\
\text { thus constrained in } \\
\text { covering the } \\
\text { operating costs of } \\
\text { the company. }\end{array}$ & $\begin{array}{l}\text { Financial burden } \\
\text { on the company } \\
\text { and delay of } \\
\text { procurement of } \\
\text { alum for the next } \\
\text { period. }\end{array}$ & $\begin{array}{l}\text { Intensifying water } \\
\text { accounts receivable } \\
\text { billing to the } \\
\text { customer or a } \\
\text { financial subsidy } \\
\text { from the } \\
\text { government. }\end{array}$ \\
\hline 6 & $\begin{array}{c}\text { Financial } \\
\text { department }\end{array}$ & $\begin{array}{l}\text { Debt of employee's } \\
\text { pension fund at } \\
\text { Dapenmapamsi. }\end{array}$ & $\begin{array}{l}\text { The lack of } \\
\text { payment of water } \\
\text { bills by customers }\end{array}$ & $\begin{array}{l}\text { Financial burden } \\
\text { on the company } \\
\text { and the } \\
\text { company's } \\
\text { employees in } \\
\text { danger of not } \\
\text { receive a pension. }\end{array}$ & $\begin{array}{l}\text { Intensifying water } \\
\text { accounts receivable } \\
\text { billing to customers. }\end{array}$ \\
\hline 7 & $\begin{array}{l}\text { Financial } \\
\text { department }\end{array}$ & $\begin{array}{l}\text { Debt of electricity } \\
\text { from PLN }\end{array}$ & $\begin{array}{l}\text { The lack of } \\
\text { payment of water } \\
\text { bills by customers }\end{array}$ & $\begin{array}{l}\text { Financial burden } \\
\text { on the company } \\
\text { and threatened } \\
\text { disconnection of } \\
\text { the electricity to } \\
\text { the company. }\end{array}$ & $\begin{array}{l}\text { Intensifying water } \\
\text { accounts receivable } \\
\text { billing to customers. }\end{array}$ \\
\hline 8 & $\begin{array}{l}\text { Financial } \\
\text { department }\end{array}$ & $\begin{array}{l}\text { Company debt of } \\
\text { the social security } \\
\text { contribution on } \\
\text { BPJS. }\end{array}$ & $\begin{array}{l}\text { The lack of } \\
\text { payment of water } \\
\text { bills by customers }\end{array}$ & $\begin{array}{l}\text { Financial burden } \\
\text { on companies and } \\
\text { potential } \\
\text { employees do not } \\
\text { receive Social }\end{array}$ & $\begin{array}{l}\text { Intensifying water } \\
\text { accounts receivable } \\
\text { billing to customers. }\end{array}$ \\
\hline
\end{tabular}




\begin{tabular}{llllll}
\hline $\begin{array}{l}\text { Code } \\
\text { R/D* }\end{array}$ & Unit & Risks & Causes & Impact & $\begin{array}{c}\text { Mitigation } \\
\text { Strategy }\end{array}$ \\
\hline
\end{tabular}

Security services

by BPJS.

\begin{tabular}{|c|c|c|c|c|c|}
\hline 9 & $\begin{array}{l}\text { Financial } \\
\text { department }\end{array}$ & $\begin{array}{l}\text { Debt of salary of } \\
\text { supervisory board. }\end{array}$ & $\begin{array}{l}\text { The lack of } \\
\text { payment of water } \\
\text { bills by customers }\end{array}$ & $\begin{array}{l}\text { Financial burden } \\
\text { on the company. }\end{array}$ & $\begin{array}{l}\text { Intensifying water } \\
\text { accounts receivable } \\
\text { billing to customers. }\end{array}$ \\
\hline 10 & $\begin{array}{l}\text { Financial } \\
\text { department }\end{array}$ & $\begin{array}{l}\text { Debt of employee } \\
\text { meal }\end{array}$ & $\begin{array}{l}\text { The lack of } \\
\text { payment of water } \\
\text { bills by customers }\end{array}$ & $\begin{array}{l}\text { Financial burden } \\
\text { on the company } \\
\text { and potentially } \\
\text { complied by } \\
\text { employees. }\end{array}$ & $\begin{array}{l}\text { Intensifying water } \\
\text { accounts receivable } \\
\text { billing to customers. }\end{array}$ \\
\hline 11 & $\begin{array}{l}\text { Adm Section } \\
\text { and General }\end{array}$ & Late order of alum. & $\begin{array}{l}\text { Constrained } \\
\text { transport from } \\
\text { Medan, North } \\
\text { Sumatra. }\end{array}$ & $\begin{array}{l}\text { Operational } \\
\text { cessation in } \\
\text { Kaway XVI and } \\
\text { Ranto Panyang. }\end{array}$ & $\begin{array}{l}\text { Borrow alum from } \\
\text { nearby counties. }\end{array}$ \\
\hline 15 & $\begin{array}{l}\text { IKK Rantau } \\
\text { Panjang }\end{array}$ & $\begin{array}{l}\text { Less stable of } \\
\text { electric current } \\
\text { from PLN }\end{array}$ & $\begin{array}{l}\text { Disruption in } \\
\text { electricity } \\
\text { generation }\end{array}$ & $\begin{array}{l}\text { Pump intake } \\
\text { could not be } \\
\text { functioned. }\end{array}$ & $\begin{array}{l}\text { Provision of a } \\
\text { backup generator to } \\
\text { overcome temporary } \\
\text { blackouts PLN. }\end{array}$ \\
\hline 17 & $\begin{array}{l}\text { IKK Rantau } \\
\text { Panjang }\end{array}$ & $\begin{array}{l}\text { Leaks in distribution } \\
\text { pipes. }\end{array}$ & $\begin{array}{l}\text { a). Excavation on } \\
\text { the road that affect } \\
\text { the pipelines } \\
\text { b). Very old } \\
\text { distribution pipe. }\end{array}$ & $\begin{array}{l}\text { Lack of water } \\
\text { pressure, so that } \\
\text { water could not } \\
\text { reach the } \\
\text { customers }\end{array}$ & $\begin{array}{l}\text { a). Improvements of } \\
\text { the leaking pipe. (B) } \\
\text { To do coordination } \\
\text { and communication } \\
\text { with the road } \\
\text { contractor }\end{array}$ \\
\hline 18 & $\begin{array}{l}\text { IKK Rantau } \\
\text { Panjang }\end{array}$ & Turbid water. & $\begin{array}{l}\text { A). Clogged / } \\
\text { damage to the } \\
\text { pump dozing. } \\
\text { (B). Shortage } \\
\text { mixture of } \\
\text { chemicals alum. } \\
\text { (C). Kerusakan on } \\
\text { WTP, but do not } \\
\text { care. }\end{array}$ & Complied by. & $\begin{array}{l}\text { (A). Do back wash } \\
\text { in tubs and tubs } \\
\text { WTP reservoir. (B). } \\
\text { Repair / } \\
\text { maintenance WTP. }\end{array}$ \\
\hline 19 & $\begin{array}{l}\text { IKK Rantau } \\
\text { Panjang }\end{array}$ & $\begin{array}{l}\text { Delays of alum } \\
\text { delivery }\end{array}$ & $\begin{array}{l}\text { Transport delays } \\
\text { from Medan, } \\
\text { North Sumatra. }\end{array}$ & $\begin{array}{l}\text { Unable to make } \\
\text { raw water } \\
\text { treatment / } \\
\text { cessation of } \\
\text { operations. } \\
\end{array}$ & $\begin{array}{l}\text { Borrowing while } \\
\text { alum in nearby } \\
\text { counties taps } \\
\text { (Nagan Raya). }\end{array}$ \\
\hline 20 & $\begin{array}{l}\text { IKK Rantau } \\
\text { Panjang }\end{array}$ & $\begin{array}{l}\text { Shortage of } \\
\text { maintenance funds. }\end{array}$ & $\begin{array}{l}\text { The company's } \\
\text { revenues had not } \\
\text { been optimal. }\end{array}$ & $\begin{array}{l}\text { Implementation } \\
\text { of the treatment } \\
\text { could not be done } \\
\text { optimally. }\end{array}$ & $\begin{array}{l}\text { Proposed } \\
\text { government } \\
\text { funding. }\end{array}$ \\
\hline
\end{tabular}




\begin{tabular}{|c|c|c|c|c|c|}
\hline $\begin{array}{l}\text { Code } \\
\text { R/D* }\end{array}$ & Unit & Risks & Causes & Impact & $\begin{array}{c}\text { Mitigation } \\
\text { Strategy }\end{array}$ \\
\hline 21 & $\begin{array}{l}\text { IKK Rantau } \\
\text { Panjang }\end{array}$ & $\begin{array}{l}\text { Distribution pumps } \\
\text { only } 1 \text { unit being } \\
\text { used of } 3 \text { units } \\
\text { available. }\end{array}$ & $\begin{array}{l}\text { Damage to the } \\
\text { second and third } \\
\text { distribution pump } \\
\text { yet there have been } \\
\text { no improvement. }\end{array}$ & $\begin{array}{l}\text { When the main } \\
\text { distribution pump } \\
\text { damage no } \\
\text { backup } \\
\text { distribution } \\
\text { pumps. }\end{array}$ & $\begin{array}{l}\text { Restoration } 2 \\
\text { distribution pumps. }\end{array}$ \\
\hline 22 & $\begin{array}{l}\text { IKK Rantau } \\
\text { Panjang }\end{array}$ & $\begin{array}{l}4 \text { units of alum } \\
\text { mixer machines and } \\
3 \text { units of alum } \\
\text { dozing machines } \\
\text { that have been } \\
\text { installed by a } \\
\text { partner since } 2015 \\
\text { were not working. }\end{array}$ & $\begin{array}{l}\text { The unit have not } \\
\text { been connected to } \\
\text { the electricity yet }\end{array}$ & $\begin{array}{l}\text { a. Mixing of } \\
\text { alum was still } \\
\text { done manually. } \\
\text { b. Injection of } \\
\text { alum into the raw } \\
\text { water and WTP } \\
\text { were still using } \\
\text { the old dozing } \\
\text { machine }\end{array}$ & $\begin{array}{l}\text { PDAM Tirta } \\
\text { Meulaboh trying to } \\
\text { reach back through } \\
\text { Satker contractor } \\
\text { concerned. }\end{array}$ \\
\hline 23 & $\begin{array}{l}\text { IKK Rantau } \\
\text { Panjang }\end{array}$ & $\begin{array}{l}\text { Water meters was } \\
\text { damaged. }\end{array}$ & $\begin{array}{l}\text { Water meters are } \\
\text { old. }\end{array}$ & $\begin{array}{l}\text { The amount of } \\
\text { water that would } \\
\text { be treated at the } \\
\text { WTP tub could } \\
\text { not be known }\end{array}$ & $\begin{array}{l}\text { The new water } \\
\text { meter procurement } \\
\text { of raw water. }\end{array}$ \\
\hline 24 & $\begin{array}{l}\text { IKK Rantau } \\
\text { Panjang }\end{array}$ & $\begin{array}{l}\text { office furniture were } \\
\text { unusable. }\end{array}$ & $\begin{array}{l}\text { Quite old office } \\
\text { furniture }\end{array}$ & $\begin{array}{l}\text { Customers who } \\
\text { came to the office } \\
\text { could not be } \\
\text { served well. }\end{array}$ & $\begin{array}{l}\text { New procurement of } \\
\text { offices furniture } \\
\text { (desks and chairs). }\end{array}$ \\
\hline 26 & $\begin{array}{l}\text { Branch of } \\
\text { Kaway XVI }\end{array}$ & Turbid water. & $\begin{array}{l}\text { (A). Heavy rain } \\
\text { which causes the } \\
\text { river water as a } \\
\text { source of raw } \\
\text { water becomes } \\
\text { cloudy. (B) Dozing } \\
\text { pump damaged. }\end{array}$ & $\begin{array}{l}\text { Complained by } \\
\text { customers }\end{array}$ & $\begin{array}{l}\text { Doing back wash in } \\
\text { the WTP and } \\
\text { reservoir tub }\end{array}$ \\
\hline 27 & $\begin{array}{l}\text { Branch of } \\
\text { Kaway XVI }\end{array}$ & $\begin{array}{l}\text { Unstable electric } \\
\text { current (often fails). }\end{array}$ & $\begin{array}{l}\text { Installation of } \\
\text { underground } \\
\text { electricity work by } \\
\text { PLN contractor }\end{array}$ & $\begin{array}{l}\text { Cease operation } \\
\text { of the machine, } \\
\text { so that water } \\
\text { could not be } \\
\text { distributed to the } \\
\text { customers }\end{array}$ & $\begin{array}{l}\text { Contacting PLN to } \\
\text { redo the work }\end{array}$ \\
\hline
\end{tabular}




\begin{tabular}{|c|c|c|c|c|c|}
\hline $\begin{array}{l}\text { Code } \\
\mathbf{R} / \mathbf{D}^{*}\end{array}$ & Unit & Risks & Causes & Impact & $\begin{array}{c}\text { Mitigation } \\
\text { Strategy }\end{array}$ \\
\hline 28 & $\begin{array}{l}\text { Branch of } \\
\text { Kaway XVI }\end{array}$ & $\begin{array}{l}\text { Most customers in } \\
\text { Blang Beurandang } \\
\text { were no not get } \\
\text { water supply. }\end{array}$ & $\begin{array}{l}\text { The installation of } \\
\text { water pipelines by } \\
\text { the NGO Caritas in } \\
2007 \text { did not } \\
\text { coordinate with the } \\
\text { PDAM Tirta } \\
\text { Meulaboh so they } \\
\text { could able to not } \\
\text { identify water } \\
\text { pipelines in that } \\
\text { area }\end{array}$ & $\begin{array}{l}\text { Most customers } \\
\text { in Blang } \\
\text { Beurandang were } \\
\text { no not get water } \\
\text { supply. }\end{array}$ & $\begin{array}{l}\text { PDAM Tirta } \\
\text { Meulaboh need to } \\
\text { identify the existing } \\
\text { gate valve at each } \\
\text { intersection in the } \\
\text { housing complex of } \\
\text { Blang Beurandang. }\end{array}$ \\
\hline 29 & $\begin{array}{l}\text { Branch of } \\
\text { Kaway XVI }\end{array}$ & $\begin{array}{l}\text { Distribution pumps } \\
\text { could not be used } \\
\text { continuously. }\end{array}$ & $\begin{array}{l}\text { Water pipelines } \\
\text { installed is not in } \\
\text { accordance with } \\
\text { the technical } \\
\text { specifications, so } \\
\text { it easy to leak } \\
\text { when the water } \\
\text { pumped } \\
\text { continuously. }\end{array}$ & $\begin{array}{l}\text { Most customers } \\
\text { in the area Blang } \\
\text { Beurandang not } \\
\text { get clean water } \\
\text { supply. }\end{array}$ & $\begin{array}{l}\text { Water distribution to } \\
\text { customers using } \\
\text { gravity. }\end{array}$ \\
\hline 30 & $\begin{array}{l}\text { Branch of } \\
\text { Kaway XVI }\end{array}$ & $\begin{array}{l}\text { Customers reluctant } \\
\text { to pay their water } \\
\text { bill. }\end{array}$ & $\begin{array}{l}\text { The water supply } \\
\text { could not reach the } \\
\text { customer and } \\
\text { murky water. }\end{array}$ & $\begin{array}{l}\text { The emergence of } \\
\text { customer } \\
\text { receivables. }\end{array}$ & $\begin{array}{l}\text { (a). Ask payment } \\
\text { from customers (b) } \\
\text { Dispensation } \\
\text { installments in } \\
\text { arrears, (c) } \\
\text { Disscount to } \\
\text { customers who pay } \\
\text { their debts at once, } \\
\text { and (d). Improve } \\
\text { the service to } \\
\text { customers. }\end{array}$ \\
\hline 31 & $\begin{array}{l}\text { Branch of } \\
\text { Kaway XVI }\end{array}$ & $\begin{array}{l}\text { Complaints from } \\
\text { customers presented } \\
\text { directly to the head } \\
\text { of the branch. }\end{array}$ & $\begin{array}{l}\text { There were no } \\
\text { employee in } \\
\text { charge to response } \\
\text { the problems. }\end{array}$ & $\begin{array}{l}\text { All complaints } \\
\text { could not be able } \\
\text { to response } \\
\text { properly }\end{array}$ & $\begin{array}{l}\text { Need to develop job } \\
\text { descriptions as } \\
\text { needed. }\end{array}$ \\
\hline 32 & $\begin{array}{l}\text { Part of } \\
\text { Customer } \\
\text { Relationship } \\
\text { and Account }\end{array}$ & $\begin{array}{l}\text { Error record water } \\
\text { meter at the } \\
\text { customer's home. }\end{array}$ & $\begin{array}{l}\text { (A). By the time } \\
\text { officer arrived to } \\
\text { the customer's } \\
\text { home to record } \\
\text { water meter, they } \\
\text { found the gate was } \\
\text { locked and nobody } \\
\text { at home (b) Blurr } \\
\text { water meter mark } \\
\text { and (c) Inaccurate } \\
\text { record by officers }\end{array}$ & $\begin{array}{l}\text { Inputting the } \\
\text { wrong data into } \\
\text { customer's water } \\
\text { bill, so it swells } \\
\text { to bill customers. }\end{array}$ & $\begin{array}{l}\text { The calculation of } \\
\text { the amount of water } \\
\text { usage was } \\
\text { conducted by } \\
\text { cubication. }\end{array}$ \\
\hline
\end{tabular}




\begin{tabular}{|c|c|c|c|c|c|}
\hline $\begin{array}{l}\text { Code } \\
\text { R/D* }\end{array}$ & Unit & Risks & Causes & Impact & $\begin{array}{c}\text { Mitigation } \\
\text { Strategy }\end{array}$ \\
\hline 33 & $\begin{array}{l}\text { Part of } \\
\text { Customer } \\
\text { Relationship } \\
\text { and Account }\end{array}$ & $\begin{array}{l}\text { Water meter was } \\
\text { lost. }\end{array}$ & $\begin{array}{l}\text { Theft of water } \\
\text { meters by } \\
\text { unknown persons. }\end{array}$ & $\begin{array}{l}\text { Losses for the } \\
\text { company and the } \\
\text { use of water } \\
\text { could not be } \\
\text { known }\end{array}$ & $\begin{array}{l}\text { Installation of the } \\
\text { iron box at the } \\
\text { customers water } \\
\text { meter }\end{array}$ \\
\hline 34 & $\begin{array}{c}\text { Part of } \\
\text { Customer } \\
\text { Relationship } \\
\text { and Account }\end{array}$ & $\begin{array}{l}\text { Complained by } \\
\text { customers }\end{array}$ & $\begin{array}{l}\text { (a)murky water } \\
\text { and (b) Swell of } \\
\text { customers water } \\
\text { bill }\end{array}$ & $\begin{array}{l}\text { Officers can } \\
\text { suffer from work } \\
\text { stress. }\end{array}$ & $\begin{array}{l}\text { Improve service to } \\
\text { customers. }\end{array}$ \\
\hline 35 & $\begin{array}{c}\text { Part of } \\
\text { Customer } \\
\text { Relationship } \\
\text { and Account }\end{array}$ & $\begin{array}{l}\text { Customer's home } \\
\text { were not be able to } \\
\text { be identified }\end{array}$ & $\begin{array}{l}\text { Initial information } \\
\text { about customer } \\
\text { data less accurate. }\end{array}$ & $\begin{array}{l}\text { Could not be able } \\
\text { to do the billing } \\
\text { to the customer's } \\
\text { account. }\end{array}$ & $\begin{array}{l}\text { Collecting data on } \\
\text { the customers }\end{array}$ \\
\hline 36 & $\begin{array}{c}\text { The Planning } \\
\text { and Control }\end{array}$ & $\begin{array}{l}\text { Data base of } \\
\text { transmission and } \\
\text { distribution } \\
\text { pipelines inaccurate. }\end{array}$ & $\begin{array}{l}\text { When new } \\
\text { pipelines added, } \\
\text { not the preliminary } \\
\text { information related } \\
\text { to existing } \\
\text { pipelines available }\end{array}$ & $\begin{array}{l}\text { (A). No work } \\
\text { efficiency when } \\
\text { conducting repair } \\
\text { leaking pipes and } \\
\text { house } \\
\text { connections, and } \\
\text { (b) Difficult to } \\
\text { detect the } \\
\text { position of gate } \\
\text { valve and the } \\
\text { mains water } \\
\text { meter when it } \\
\text { leakage }\end{array}$ & $\begin{array}{l}\text { Redo the mapping } \\
\text { existing pipelines } \\
\text { network }\end{array}$ \\
\hline 37 & $\begin{array}{c}\text { The Planning } \\
\text { and Control }\end{array}$ & $\begin{array}{l}\text { Installation of } \\
\text { transmission and } \\
\text { distribution } \\
\text { pipelines by the } \\
\text { contractor did not } \\
\text { comply with the } \\
\text { specification. }\end{array}$ & $\begin{array}{l}\text { Did it on purpose } \\
\text { by contractors }\end{array}$ & $\begin{array}{l}\text { Easy leak in the } \\
\text { transmission and } \\
\text { distribution } \\
\text { pipelines. }\end{array}$ & $\begin{array}{l}\text { Conduct parallel } \\
\text { surveillance by } \\
\text { PDAM Tirta } \\
\text { Meulaboh at the } \\
\text { time of installation } \\
\text { of the pipeline by } \\
\text { the contractor. }\end{array}$ \\
\hline 38 & $\begin{array}{c}\text { The Planning } \\
\text { and Control }\end{array}$ & $\begin{array}{l}\text { Monitoring software } \\
\text { for water pressure } \\
\text { was not yet } \\
\text { available }\end{array}$ & Lack of funds. & $\begin{array}{l}\text { Decision-making } \\
\text { in the } \\
\text { management of } \\
\text { water could not } \\
\text { be done on time. }\end{array}$ & $\begin{array}{l}\text { Proposed support } \\
\text { from the } \\
\text { government, both } \\
\text { local and central } \\
\text { government }\end{array}$ \\
\hline 41 & $\begin{array}{c}\text { Warehousing } \\
\text { Dept. }\end{array}$ & Flood & $\begin{array}{l}\text { Rain and low } \\
\text { warehouse } \\
\text { building } \\
\text { foundation }\end{array}$ & $\begin{array}{l}\text { Caused the items } \\
\text { store in the } \\
\text { warehouse } \\
\text { damage, such as: } \\
\text { water meter, } \\
\text { water meter } \\
\text { accessories and } \\
\text { other items. }\end{array}$ & $\begin{array}{l}\text { Renovation of the } \\
\text { warehouse }\end{array}$ \\
\hline
\end{tabular}




\begin{tabular}{|c|c|c|c|c|c|}
\hline $\begin{array}{l}\text { Code } \\
\text { R/D* }\end{array}$ & Unit & Risks & Causes & Impact & $\begin{array}{l}\text { Mitigation } \\
\text { Strategy }\end{array}$ \\
\hline 42 & $\begin{array}{l}\text { Production } \\
\text { Dept. }\end{array}$ & Turbid water. & $\begin{array}{l}\text { (A). Due to heavy } \\
\text { rain (b). Because } \\
\text { of the hot weather, } \\
\text { (c). Damage of } \\
\text { dozing pump (d) } \\
\text { Lack of focus of } \\
\text { officers who } \\
\text { preparing } \\
\text { chemicals for } \\
\text { injection to the } \\
\text { WTP. }\end{array}$ & $\begin{array}{l}\text { Complained by } \\
\text { customers }\end{array}$ & $\begin{array}{l}\text { (A). Chcek the water } \\
\text { condition } \\
\text { periodically (every } 2 \\
\text { hours) (b). When the } \\
\text { source of raw water } \\
\text { turbid, then the } \\
\text { operator must be } \\
\text { alert in adjusting the } \\
\text { dozing pump } \\
\text { engines and increase } \\
\text { the use of alum, and } \\
\text { (c) Operator should } \\
\text { able to read nature } \\
\text { signs to be ready of } \\
\text { heavy rain. }\end{array}$ \\
\hline 43 & $\begin{array}{l}\text { Production } \\
\text { Dept. }\end{array}$ & $\begin{array}{l}\text { Burning of the } \\
\text { intake pump }\end{array}$ & $\begin{array}{l}\text { (A). Sedimentation } \\
\text { of mud and } \\
\text { garbage enter to } \\
\text { vacuum machine } \\
\text { (well pump), (b) } \\
\text { unstable PLN } \\
\text { electricity }\end{array}$ & $\begin{array}{l}\text { Cease operation } \\
\text { of intake pump }\end{array}$ & $\begin{array}{l}\text { (A) Do the cleaning } \\
\text { the intake structure } \\
\text { for at least } 6 \text { months } \\
\text { to } 1 \text { year, (B) } \\
\text { Operator obliged to } \\
\text { check the sludge } \\
\text { sediment intake } \\
\text { structure, (c) } \\
\text { Contact PLN to } \\
\text { stabilize the electric } \\
\text { current. }\end{array}$ \\
\hline 46 & $\begin{array}{l}\text { Production } \\
\text { Dept. }\end{array}$ & Red colored water. & $\begin{array}{l}\text { (A). Due to natural } \\
\text { factors, such as } \\
\text { rain, and (b) Red } \\
\text { Leuhan river water } \\
\text { enter to the intake } \\
\text { due to the rainy } \\
\text { season. }\end{array}$ & $\begin{array}{l}\text { Complied by } \\
\text { customer. }\end{array}$ & $\begin{array}{l}\text { (A). Relocating the } \\
\text { intake structure } \\
\text { passed through / } \\
\text { over the mouth of } \\
\text { the river Leuhan, } \\
\text { and B). Adding raw } \\
\text { water suction pipe } \\
\text { length. }\end{array}$ \\
\hline
\end{tabular}




\begin{tabular}{|c|c|c|c|c|c|}
\hline $\begin{array}{l}\text { Code } \\
\text { R/D* }\end{array}$ & Unit & Risks & Causes & Impact & $\begin{array}{c}\text { Mitigation } \\
\text { Strategy }\end{array}$ \\
\hline 48 & $\begin{array}{l}\text { Production } \\
\text { Dept. }\end{array}$ & $\begin{array}{l}\text { Laboratory } \\
\text { equipment } \\
\text { incomplete and } \\
\text { laboratory reagents } \\
\text { have been expired. }\end{array}$ & $\begin{array}{l}\text { Companies are } \\
\text { constrained in } \\
\text { financial terms. }\end{array}$ & $\begin{array}{l}\text { The company } \\
\text { could not } \\
\text { conduct } \\
\text { examination of } \\
\text { biological and } \\
\text { chemical water so } \\
\text { that the water } \\
\text { supplied to } \\
\text { customers did not } \\
\text { meet the } \\
\text { conditions } \\
\text { required by the } \\
\text { Minister of } \\
\text { Health. }\end{array}$ & $\begin{array}{l}\text { Proposed funding } \\
\text { support from local } \\
\text { government, } \\
\text { provincial } \\
\text { government and } \\
\text { central government }\end{array}$ \\
\hline 49 & $\begin{array}{l}\text { Production } \\
\text { Dept. }\end{array}$ & $\begin{array}{l}\text { Water meter } \\
\text { production was } \\
\text { damaged }\end{array}$ & $\begin{array}{l}\text { Rubbish is often } \\
\text { caught in the } \\
\text { propeller water } \\
\text { meter, thereby } \\
\text { disrupting the } \\
\text { supply of water } \\
\text { from the intake to } \\
\text { the WTP. }\end{array}$ & $\begin{array}{l}\text { Not be able to } \\
\text { measure the } \\
\text { amount of water } \\
\text { produced in the } \\
\text { WTP. }\end{array}$ & $\begin{array}{l}\text { Procurement of } \\
\text { digital production } \\
\text { water meter }\end{array}$ \\
\hline 50 & $\begin{array}{l}\text { Production } \\
\text { Dept. }\end{array}$ & $\begin{array}{l}\text { Water meter } \\
\text { distribution was } \\
\text { damaged. }\end{array}$ & $\begin{array}{l}\text { Rubbish is often } \\
\text { caught in the } \\
\text { propeller water } \\
\text { meter that disrupts } \\
\text { water supply from } \\
\text { the reservoir basin } \\
\text { to customers. }\end{array}$ & $\begin{array}{l}\text { Not be able to } \\
\text { measure the } \\
\text { amount of water } \\
\text { distributed to } \\
\text { customers }\end{array}$ & $\begin{array}{l}\text { Procurement of } \\
\text { digital distribution } \\
\text { water meter }\end{array}$ \\
\hline 51 & $\begin{array}{l}\text { Production } \\
\text { Dept. }\end{array}$ & $\begin{array}{l}\text { There is no water } \\
\text { meter for water } \\
\text { tank car. }\end{array}$ & $\begin{array}{l}\text { Procurement has } \\
\text { not been done yet }\end{array}$ & $\begin{array}{l}\text { The potential } \\
\text { occurrence of } \\
\text { fraud and } \\
\text { potential loss of } \\
\text { water. }\end{array}$ & $\begin{array}{l}\text { Procurement of } \\
\text { water meters for } \\
\text { water collection by } \\
\text { tank car. }\end{array}$ \\
\hline
\end{tabular}




\begin{tabular}{|c|c|c|c|c|c|}
\hline $\begin{array}{l}\text { Code } \\
\text { R/D* }\end{array}$ & Unit & Risks & Causes & Impact & $\begin{array}{l}\text { Mitigation } \\
\text { Strategy }\end{array}$ \\
\hline 52 & $\begin{array}{l}\text { Transmissio } \\
\mathrm{n} \text { and } \\
\text { Distribution } \\
\text { Section }\end{array}$ & $\begin{array}{l}\text { Leaks in the } \\
\text { transmission and } \\
\text { distribution } \\
\text { pipelines. }\end{array}$ & $\begin{array}{l}\text { (A) Pipelines were } \\
\text { already old, (b) } \\
\text { excavation of road } \\
\text { and (c) installment } \\
\text { of underground } \\
\text { Telkom cable } \\
\text { network. }\end{array}$ & $\begin{array}{l}\text { (A) .Distrupt } \\
\text { water supply to } \\
\text { customers, (b). } \\
\text { The water } \\
\text { pressure is } \\
\text { reduced, and (c) } \\
\text { create loss to the } \\
\text { company. }\end{array}$ & $\begin{array}{l}\text { (A). Fixing leaky } \\
\text { pipes, (b). } \\
\text { Coordinate with the } \\
\text { Department of } \\
\text { Public Works and } \\
\text { Telkom during the } \\
\text { excavation of the } \\
\text { road to avoid pipe } \\
\text { leaking in the future. }\end{array}$ \\
\hline 53 & $\begin{array}{l}\text { Transmissio } \\
\mathrm{n} \text { and } \\
\text { Distribution } \\
\text { Section }\end{array}$ & $\begin{array}{l}\text { The occurrence of } \\
\text { illegal connections }\end{array}$ & $\begin{array}{l}\text { Lack of } \\
\text { supervision from } \\
\text { internal of the } \\
\text { company }\end{array}$ & $\begin{array}{l}\text { Detrimental to the } \\
\text { company. }\end{array}$ & $\begin{array}{l}\text { (a).Improve the } \\
\text { supervision, } \\
\text { (b).Stop the } \\
\text { connection (c).Fine } \\
\text { up to Rp2 } \\
\text { mil/month) }\end{array}$ \\
\hline 54 & $\begin{array}{l}\text { Transmissio } \\
\mathrm{n} \text { and } \\
\text { Distribution } \\
\text { Section }\end{array}$ & $\begin{array}{l}\text { The water supply to } \\
\text { the customer was } \\
\text { stop }\end{array}$ & $\begin{array}{l}\text { (a). Leaking } \\
\text { pipelines } \\
\text { (b). Distribution } \\
\text { pipe to the } \\
\text { customers was not } \\
\text { flow smoothly } \\
\text { (c). Murky water. }\end{array}$ & $\begin{array}{l}\text { Complained by } \\
\text { customers. }\end{array}$ & $\begin{array}{l}\text { (a). Repair and clean } \\
\text { the leak pipe. (b). } \\
\text { Install new } \\
\text { pipelines. }\end{array}$ \\
\hline
\end{tabular}

\section{CONCLUSION}

At PDAM Tirta Meulaboh there were 43 risk events that have the potential dangers, which if not be handled immediately may affect the company's performance and even survival of the company. Of the 43 potential risks that logged to the red zone, there were 5 potential risks in the first rank, 21 potential risks in the second rank and the remaining 17 potential risks were in the third rank.

As for the 5 potential risks in the first rank were in the production department: the defective of production water meter, the defective of distribution water meter wate and water meter of tank car was not functioning . In branch of Kaway XVI: customers were reluctant to pay the water bill and in the IKK Rantau Panjang: water meter of raw water damaged.

Efforts to mitigate against the 43 risks logged in the red zone have not been planned and done by the management of PDAM Tirta Meulaboh yet.

\section{References}

Abisay, T.G., \& Nurhadi. (2013). Manajemen Risiko pada Bandara Soekarno Hatta Berbasis ISO 31000. Jurnal Teknik Industri, 14 (2), 116-129. 
CPPR MEP UGM-Kemitraan. (2012). Modul Manajemen Risiko LPSE. Yogyakarta: Penerbit Magister Ekonomika Pembangunan UGM.

Dewi, D. (2012). Penerapan Sistem Manajemen Risiko pada Industri Nasional sebagai Masukan untuk Program PLTN. Prosiding Seminar Nasional Pengembangan Energi Nuklir V, 2012, Jakarta, Indonesia, 68-76, ISSN: 19791208.

Febriyanti, A., \& Hidayanto, B.C., (2012). Manajemen Risiko pada Pengelolaan Data di Bagian Pengolahan Data PT Petrokimia Gresik. Jurnal Teknik Pomits, 1 (1), 1-6.

Hanggraeni, D. (2015). Enterprise Risk Management and Good Corporate Governance. Jakarta: Penerbit Universitas Indonesia. ISBN: 978-979-456555-1

Hanafi, M.M. (2014). Manajemen Risiko. Yogyakarta: Penerbit UPPM STIM YKPN. ISBN: 878-879-3532-61-5.

Li Guo. (2015). Implementation of a Risk Management Plan in a Hospital Operating Room. International Journal of Nursing Sciences. ElsevierScienceDirect, 348 - 354 .

Nurochman, A. (2014). Manajemen Risiko Sistem Informasi Perpustakaan (Studi Kasus di Perpustakaan Universitas Gajah Mada Yogyakarta). Jurnal Berkala Ilmu Perpustakaan dan Informasi, X (2), 1-13.

Peltier, T.R. (2004). Risk Analysis and Risk Management. Information System Security, 13 (4). 44-56.

Susilo, L.J., \& Kaho, V.R. (2010). Manajemen Risiko Berbasis ISO 31000. Jakarta: Penerbit PPM. ISBN: 979-442-271-1.

Tugiman, H. (2009). Manajemen Risiko Organisasi. Jurnal Manajemen Indonesia, 9 (1), 36-64. 